\title{
PENERAPAN E-LEARNING SEBAGAI MEDIA PEMBELAJARAN JARAK JAUH UNTUK MENINGKATKAN HASIL BELAJAR MATA PELAJARAN FIQIH DI MTs NEGERI 5 KLATEN
}

\author{
HARYANI \\ MTs Negeri 5 Klaten, Jawa Tengah \\ E-mail : draharyanitulas@gmail.com
}

\begin{abstract}
ABSTRAK
Penelitian ini bertujuan untuk meningkatkan hasil belajar peserta didik mata pelajaran Fiqih dalam pembelajaran jarak jauh (daring) dengan memanfaatkan aplikasi e-learning sebagai media pembelajaran mata pelajaran Fiqih di MTs Negeri 5 Klaten .Dampak dari pandemi Covid 19 dalam dunia pendidikan menyebabkan aktifitas belajar dilaksanakan secara daring atau pembelajaran jarak jauh. Tidak bertemunya pendidik dengan anak didik dalam proses pembelajaran tentu saja akan berpengaruh terhadap hasil belajar karena peserta didik kurang semangat,pasif dan jenuh dalam mengikuti pembelajaran.Hal itu mengakibatkan hasil belajar peserta didik sangat rendah dan pendidik juga kesulitan dalam melaksanakan proses pembelajaran .Oleh karena itu diperlukan media pembelajaran yang efektif dan efisien. Penelitian ini adalah penelitian tindakan kelas dan dilaksanakan dengan 2 siklus. Subyek penelitian ini adalah siswa kelas VIII A MTs Negeri 5 Klaten sebanyak 24 siswa. Tehnik pengumpulan data dengan tes dan dokumentasi. Analisis data dengan tehnik diskriptif kuantitatif.Dari hasil analisis data sebelum tindakan nilai rata-rata hasil belajar siswa sebesar 50,42. Pada siklus I terjadi peningkatan rata-rata hasil belajar siswa sebesar 80,41. Kemudian di akhir siklus II rata - rata hasil belajar siswa meningkat sebesar 89,58.Kesimpulan pemanfaatan e-learning sebagai media pembelajarn jarak jauh di MTs Negeri 5 Klaten dapat meningkatkan hasil belajar peserta didik.
\end{abstract}

Kata kunci : E-learning, Media pembelajaran, Hasil belajar

PENDAHULUAN

Pembelajaran merupakan proses yang sangat penting dalam mewariskan nilai-nilai pengetahuan, kepribadian dan karakter serta akhlak mulia. Dalam mentransfer nilai-nilai tersebut sangat dipengaruhi oleh beberapa faktor diantaranya faktor anak didik dan pendidik. Dari faktor anak didik ,faktor internal pribadi anak yang meliputi inteligensi,bakat,minat,sikap dan motivasi juga sangat mempengaruhi hasil belajar.Pembelajaran tidak akan berhasil jika tidak ada minat ,motivasi dan sikap yang sungguh-sungguh dalam belajar. Dari faktor guru pemilihan media pembelajaran yang kurang tepat juga akan mempengaruhi keberhasilan proses pembelajaran. Menurut Syaiful Bahri Djamarah dan Aswan Zain(2010:121) media pembelajaran adalah alat bantu apa saja yang dapat dijadikan sebagai penyalur pesan agar tercapai tujuan pembelajaran. Dalam buku Azhar Arsyad (2005: 15) bahwa, pemakaian media pembelajaran dalam proses belajar mengajar dapat membangkitkan keinginan dan minat yang baru, membangkitkan motivasi dan rangsangan kegiatan belajar, dan bahkan membawa pengaruh-pengaruh psikologis terhadap siswa.

Sejak diberlakukannya Surat Edaran Menteri Pendidikan dan kebudayaan Nomor 4 Tahun 2020 tentang Pelaksanaan Kebijakan Pendidikan dalam Masa Darurat (COVID - 19) bahwa Pendidikan dilaksanakan dari rumah melalui pembelajaran jarak jauh baik daring ataupun luring. Penerapan model pembelajaran daring sebenarnya telah dilaksanakan di negara-negara maju namun untuk satuan pendidikan menengah di Indonesia masih merupakan hal yang baru bahkan juga menimbulkan permasalahan baru bagi peserta didik maupun pendidik. Ketidakhadiran sosok guru,penggunaan media daring yang belum optimal,keterbatasan orang tua dalam mendampingi anak-anaknya merupakan masalah yang menyebabkan kurang antusias dalam belajar yang akhirnya menyebabkan rendahnya hasil belajar peserta didik. Sedangkan bagi pendidik yang kurang menguasai IT juga merasakan 
beban yang sangat berat dalam menyampaikan proses pembelajaran,bahkan masih bingung mencari cara /model menyampaikan pembelajaran yang akhirnya anak hanya diberi tugas mengerjakan LKS melalui pesan Whatsap. Dalam pembelajaran daring ini bukan berarti guru hanya memberikan tugas tanpa melibatkan aktifitas peserta didik dalam tahapan pembelajaran. Rendahnya aktifitas peserta didik dapat berpengaruh terhadap hasil belajar. Rizwan (2016) menyatakan bahwa kurangnya aktifitas dan motivasi peserta didik selama proses pembelajaran berlangsung berdampak pada rendahnya hasil belajar. Untuk itu seorang pendidik dituntut untuk bisa menciptakan pembelajaran sesuai keadaan dengan memanfaatkan Teknologi Informasi dan Komunikasi. Seperti yang dinyatakan oleh Jauharul (2016) bahwa pengembangan aplikasi berbasis Teknologi Informasi dan Komunikasi (TIK) sangat tepat sekali guna meningkatkan kualitas pembelajaran.

Perlu adanya upaya perubahan yang dilakukan untuk meningkatkan hasil belajar siswa dalam pembelajaran daring,diantaranya adalah penerapan media pembelajaran yang tepat dan membangkitkan motivasi serta minat belajar siswa. Pemerintah melalui kementerian agama RI telah menyediakan aplikasi E-Learning Madrasah versi 2.0.0 yang sangat lengkap untuk mendukung proses pembelajaran jarak jauh. Dalam E-Learning Madrasah versi 2.0.0 guru dapat menyampaikan bahan ajar dalam berbagai pilihan seperti: format Ms word,format PDF,format Excel,format Power point,video,link artikel dan gambar (format jpg), yang tentunya lebih bervariasi dan menyenangkan bagi peserta didik. Oleh karena itu penulis tertarik untuk mengadakan penelitian tentang penerapan E-Learning Madrasah versi 2.0.0 sebagai media pembelajaran jarak jauh di MTs Negeri 5 Klaten. Dengan penelitian ini diharapkan penerapan E-Learning Madrasah versi 2.0.0 sebagai media pembelajaran jarak jauh dapat meningkatkan hasil belajar siswa mata pelajaran Fiqih di MTs Negeri 5 Klaten.

\section{METODE PENELITIAN}

Prosedur penelitian ini adalah penelitian tindakan kelas. Rancangan yang digunakan adalah model rancangan yang dikembangkan oleh Stephen Kemmis dan Mc.Taggart (dalam Arikunto,2008:97) dengan menggunakan dua siklus dan masing-masing siklus dilaksanakan dalam 2 kali pertemuan. Tiap siklus terdiri dari 4 tahap yaitu 1) Perencanaan, 2) Pelaksanaan tindakan, 3) Observasi ( pengamatan), 4) Refleksi. Berikut ini adalah gambar rancangan penelitian tindakan kelas menurut Stephen Kemmis dan McTaggart.

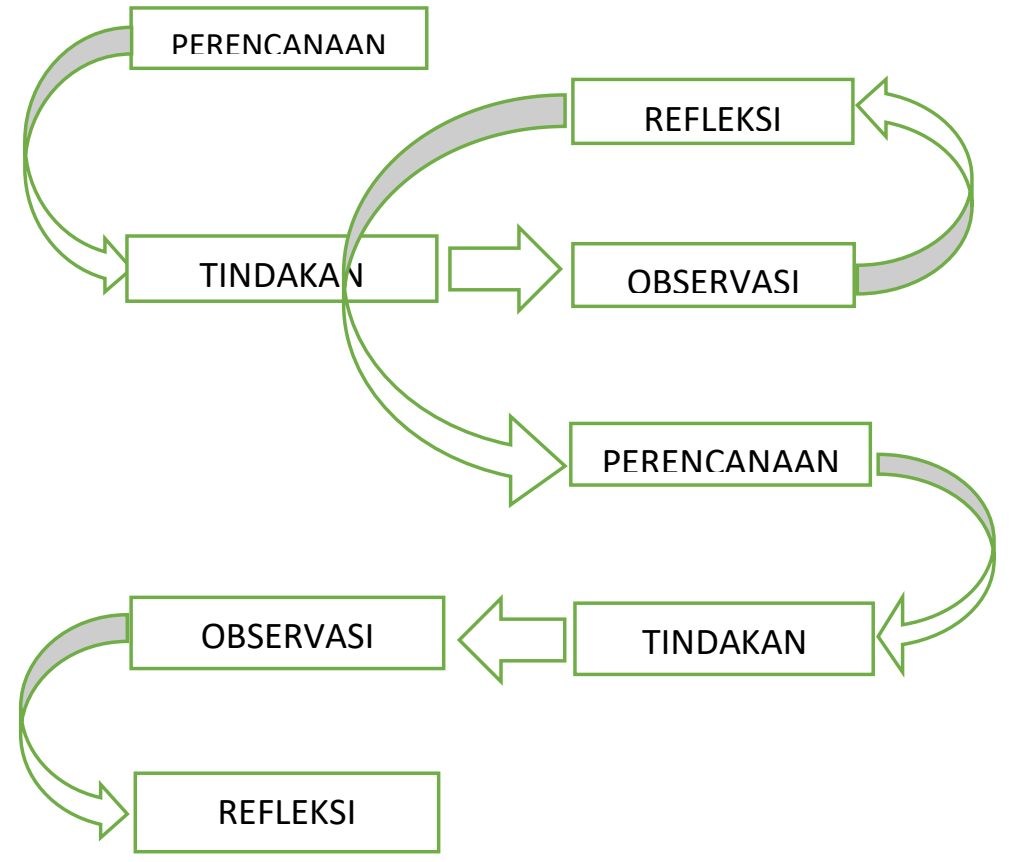

Gambar 1. Tahapan dalam siklus Penelitian Tindakan Kelas Model Kemmis \& Taggart. 
Penelitian Tindakan Kelas ini dilaksanakan dengan langkah-langkah penelitian yang telah direncanakan. Pada siklus 1 tahap perencanaan dimulai dengan penyusunan perangkat pembelajaran secara lengkap (RPP yang berisi langkah-langkah dalam pelaksanaan pembelajaran,bahan ajar,metode,alat/media pembelajaran,dan evaluasi),melakukan kordinasi dengan rekan sejawat dan siswa,serta menyiapkan perangkat keras dan lunak untuk pelaksanaan pembelajaran daring melalui media pembelajaran aplikasi E-Learning Madrasah. Selanjutnya tahap pelaksanaan tindakan yaitu pelaksanaan pembelajarana daring dengan media pembelajaran aplikasi E-Learning Madrasah versi2.0.0 yang di kembangkan oleh kementerian Agama RI . Langkah selanjutnya adalah pengumpulan data yang dilakukan melalui observasi ,pre test maupun post test. Setelah data diperoleh dari penelitian ini yang berupa data awal yang didapatkan dari data pra tindakan ,data pada saat tindakan dan data hasil tindakan,langkah berikutnya adalah tahap refleksi yaitu tahap dimana hasil pengamatan dan evaluasi tindakan yang telah dilakukan dalam pembelajaran dikumpulkan,dianalisis dan diskusikan dengan teman sejawat dan kolaborator. kemudian direfleksikan dan digunakan sebagai dasar acuan rancangan pada siklus II. Dalam siklus II hasil refleksi pada siklus I digunakan untuk merencanakan dan merancang tindakan pada siklus II. Kegiatan pada siklus II ini meliputi perencanaan yang berupa identifikasi dan penentuan alternatif pemecahan masalah serta pengembangan program pembelajaran melalui media E-Learning Madrasah, pelaksanaan tindakan dilanjutkan dengan pengumpulan data dan analisis dan yang terakhir adalah evaluasi dan pengambilan kesimpulan. Subyek penelitian ini adalah peserta didik kelas VIII A MTs Negeri 5 Klaten Semester Gasal Tahun pelajaran 2020/2021 yang berjumlah 24 siswa.

Obyek penelitian ini adalah hasil belajar peserta didik pada saat pembelajaran jarak jauh (daring) melalui media pembelajaran aplikasi E-Learning Madrsah. Metode pengumpulan data pada penelitian tindakan kelas ini adalah menggunakan metode tes dan dokumentasi pada saat mengikuti pembelajaran melalui aplikasi E-Learning Madrasah. Aspek yang menjadi tolok ukur keberhasilan penelitian ini adalah adanya peningkatan hasil belajar siswa yang ditunjukkan dengan kenaikan nilai rata-rata dari sebelum tindakan dan kenaikan nilai rata-rata setelah tindakan serta kenaikan prosentase ketuntasan belajar peserta didik dengan Kreteria Ketuntasan Minimal (KKM) mata pelajaran Fiqih yaitu 67.

Teknik analisis data pada penelitian tindakan kelas ini adalah diskriptif kuantitatif. Dimana data hasil belajar siswa dianalisis dengan cara menjumlahkan skor perolehan dibagi dengan skor maksimal kemudian dikalikan 100. Adapun rumus penilaiannya menggunakan rumus menurut Suharsimi Arikunto (2002:183) . Berikut rumusnya

$$
\text { Skor/Nilai }=\frac{\sum \text { skor perolehan }}{\sum \text { skor maksimal }} \times 100
$$

Kemudian kita hitung nilai rata-rata kelas dengan cara menjumlahkan skor nilai perolehan seluruh peserta didik dibagi jumlah peserta didik yang mengikuti tes dengan rumus :

$$
\begin{aligned}
& \text { Nilai rata-rata }=\frac{\sum \mathrm{X}}{\sum \mathrm{N}} \\
& \text { Keterangan }= \\
& \sum \mathrm{X} \quad=\text { Jumlah nilai seluruh siswa } \\
& \sum \mathrm{N} \quad \text { = Jumlah siswa yang mengikuti tes }
\end{aligned}
$$


Setelah diketahui rata-rata kelas selanjutnya nilai hasil belajar siswa dikualifikasikan dengan menggunakan pedoman sebagai berikut :

Tabel 1: Tabel Kualifikasi Nilai Rata-Rata Kelas

\begin{tabular}{|l|c|l|}
\hline No & Nilai Rata-Rata Kelas & Kualifikasi \\
\hline 1. & $81 \leq X \leq 100$ & Baik \\
\hline 2. & $61 \leq X \leq 80$ & Cukup \\
\hline 3. & $41 \leq X \leq 60$ & Kurang \\
\hline 4. & $21 \leq X \leq 40$ & Rendah \\
\hline 5. & $0 \leq X \leq 20$ & Sangat Rendah \\
\hline
\end{tabular}

Keterangan : $\mathrm{X}=$ Nilai rata-rata kelas

Selanjutnya kita akan menilai ketuntasan hasil belajar siswa. Dalam penelitian ini terdapat dua kreteria ketuntasan belajar yaitu secara individual dan klasikal. Ketuntasan belajar secara individual didapat dari Kreteria Ketuntasan Minimal mata pelajaran Fiqih kelas VIII MTs Negeri 5 Klaten Semester Gasal tahun Pelajaran 2020/2021 yaitu 67,dengan kreteria jika hasil belajar siswa sekuarng-kurangnya mendapatkan nilai 67 maka siswa tersebut dinyatakan tuntas dan jika hasil belajar siswa mendapatkan nilai kurang dari 67 maka siswa tersebut dinyatakan tidak tuntas. Sedangkan ketuntasan belajar secara klasikal adalah mengukur tingkat ketuntasan belajar siswa keseluruhan. Adapun cara menghitung prosentase ketuntasan belajar secara klasikal digunakan rumus :

$$
\sum \text { ( Jumlah siswa yang mendapatkan nilai } \geq 67 \text { ) }
$$

Prosentase $=$ X 100 $\sum$ ( Jumlah siswa yang mengikuti tes )

Selanjutnya data tersebut dikualifikasikan dengan menggunakan pedoman sebagai berikut

Tabel 2 :Tabel Kualifikasi Prosentase ketuntasan Hasil belajar

\begin{tabular}{|l|c|l|}
\hline No & Prosentase & \multicolumn{1}{|c|}{ Kualifikasi } \\
\hline 1. & $81 \leq X \leq 100$ & Baik \\
\hline 2. & $61 \leq X \leq 80$ & Cukup \\
\hline 3. & $41 \leq X \leq 60$ & Kurang \\
\hline 4. & $21 \leq X \leq 40$ & Rendah \\
\hline 5. & $0 \leq X \leq 20$ & Sangat Rendah \\
\hline
\end{tabular}

Keterangan : $\mathrm{X}=$ prosentase ketuntasan hasil belajar

\section{HASIL DAN PEMBAHASAN}

Hasil belajar peserta didik pada awal pembelajaran jarak jauh (daring) dimana pembelajaran masih menggunakan pesan singkat lewat Whatsaap masih menunjukkan kualifikasi cukup rendah yaitu dengan rata-rata kelas sebesar 50,42. Berikut daftar hasil belajar peserta didik pada tahap pra siklus :

Gambar 3: Tabel Nilai Ketuntasan Hasil Belajar Peserta Disik Pada Pelaksanaan Pra Siklus

\begin{tabular}{|l|l|c|l|}
\hline No & Nama & Nilai & Keterangan \\
\hline 1 & Achmad Gerrad Abdul Hafidz & 100 & Tuntas \\
\hline 2 & Muhammad Rizqi Firdaus & 100 & Tuntas \\
\hline 3 & Anggi Adelia & 90 & Tuntas \\
\hline 4 & Muhammad Fathun Ni'am & 90 & Tuntas \\
\hline
\end{tabular}




\begin{tabular}{|l|l|c|l|}
\hline 5 & Nanda Hermawan & 90 & Tuntas \\
\hline 6 & Cinde Mas K Wijoyo Witjaksono & 80 & Tuntas \\
\hline 7 & Erlin Febriyanti & 70 & Tuntas \\
\hline 8 & Ridwan Adi Kusuma & 70 & Tuntas \\
\hline 9 & Difa tri Lestari & 70 & Tuntas \\
\hline 10 & Kirena Yuki Mustikaningrum & 70 & Tuntas \\
\hline 11 & Luthfia Rahmawati & 70 & Tuntas \\
\hline 12 & Bunga Cesaria Agustin & 50 & Belum tuntas \\
\hline 13 & Malik Fajar Muhammad & 50 & Belum tuntas \\
\hline 14 & Zulfa Agustin & 50 & Belum tuntas \\
\hline 15 & Syifa Ayu Rahmadhanti & 40 & Belum tuntas \\
\hline 16 & Bilqis Chairunnisa' Azzura Sutrisno & 30 & Belum tuntas \\
\hline 17 & Nayshila Rasya fauziah & 30 & Belum tuntas \\
\hline 18 & Fathia Aziza Nirmala & 20 & Belum tuntas \\
\hline 19 & Firnanda Kusuma & 20 & Belum tuntas \\
\hline 20 & Silvia fatehatu Rahma & 20 & Belum tuntas \\
\hline 21 & Diva Faulisa Ariana & 0 & tidak mengikuti tes \\
\hline 22 & Fiqhan Rodzian & 0 & tidak mengikuti tes \\
\hline 23 & Firda Shakiyah Nia Aprilia & 0 & tidak mengikuti tes \\
\hline 24 & Fitri Wulandari & 0 & tidak mengikuti tes \\
\hline & Jumlah Nilai & 1210 & \\
\hline & Jumlah Nilai maksimal & 2400 & \\
\hline & Rata-rata kelas & 50,42 & \\
\hline & Ketuntasan Belajar & $45,83 \%$ & \\
\hline
\end{tabular}

Tabel 4: Tabel Prosentase Nilai Ketuntasan Belajar Pada Pelaksanaan Pra Siklus

\begin{tabular}{|c|l|l|l|}
\hline $\begin{array}{l}\text { Kreteria Ketuntasan } \\
\text { Minimal (KKM) 67 }\end{array}$ & $\begin{array}{l}\text { Frekuensi } \\
\text { (Peserta didik) }\end{array}$ & Prosentase & Keterangan \\
\hline$\geq 67$ & 11 & $45,83 \%$ & Tuntas \\
\hline$<67$ & 13 & $55,17 \%$ & Belum Tuntas \\
\hline Nilai terendah & 20 & & \\
\hline Nilai tertinggi & 100 & & \\
\hline
\end{tabular}

Tabel 3 menunjukkan rata-rata hasil belajar sebelum tindakan sebesar 50,42 dan Gambar 4 menunjukkan prosentase ketuntasan belajar siswa secara klasikal masih di bawah KKM. Faktor utama penyebab rendahnya hasil belajar peserta didik adalah rendahnya aktifitas peserta didik yang disebabkan oleh proses pembelajaran jarak jauh yang belum maksimal, kejenuhan peseerta didik dalam mengikuti pembelajaran jarak jauh karena pembelajaran hanya menggunakan pesan singkat whatsaap. Bahkan masih ada beberapa anak yang tidak mengikuti tes.

Selanjutnya nilai hasil belajar mata pelajaran Fiqih kelas VIII A Mts Negeri 5 Klaten semester Gasal Tahun Pelajaran 2020/2021 pada siklus I sebagai berikut :

Tabel 5: Tabel Nilai Ketuntasan Hasil Belajar Peserta Didik Mata Pelajaran Fiqih Kelas VIII A MTs Negeri 5 Klaten Pada siklus I

\begin{tabular}{|l|l|c|l|}
\hline No & Nama Peserta Didik & Nilai & Keterangan \\
\hline 1 & Achmad Gerrad Abdul Hafidz & 100 & Tuntas \\
\hline 2 & Muhammad Rizqi Firdaus & 100 & Tuntas \\
\hline 3 & Anggi Adelia & 100 & Tuntas \\
\hline
\end{tabular}




\begin{tabular}{|l|l|c|l|}
\hline 4 & Muhammad Fathun Ni'am & 100 & Tuntas \\
\hline 5 & Nanda Hermawan & 100 & Tuntas \\
\hline 6 & Kirena Yuki Mustikaningrum & 100 & Tuntas \\
\hline 7 & Luthfia Rahmawati & 100 & Tuntas \\
\hline 8 & Diva Faulisa Ariana & 100 & Tuntas \\
\hline 9 & Cinde Mas K Wijoyo Witjaksono & 90 & Tuntas \\
\hline 10 & Erlin Febriyanti & 90 & Tuntas \\
\hline 11 & Ridwan Adi Kusuma & 90 & Tuntas \\
\hline 12 & Silvia fatehatu Rahma & 90 & Tuntas \\
\hline 13 & Firda Shakiyah Nia Aprilia & 90 & Tuntas \\
\hline 14 & Fitri Wulandari & 90 & Tuntas \\
\hline 15 & Malik Fajar Muhammad & 90 & Tuntas \\
\hline 16 & Zulfa Agustin & 80 & Tuntas \\
\hline 17 & Syifa Ayu Rahmadhanti & 80 & Tuntas \\
\hline 18 & Nayshila Rasya fauziah & 80 & Tuntas \\
\hline 19 & Fathia Aziza Nirmala & 70 & Tuntas \\
\hline 20 & Bunga Cesaria Agustin & 50 & Tidak tuntas \\
\hline 21 & Difa tri Lestari & 50 & Tidak tuntas \\
\hline 22 & Bilqis Chairunnisa' Azzura Sutrisno & 30 & Tidak tuntas \\
\hline 23 & Firnanda Kusuma & 30 & Tidak tuntas \\
\hline 24 & Fiqhan Rodzian & 30 & Tidak tuntas \\
\hline & Jumlah Nilai & 1930 & \\
\hline & Jumlah Nilai Maksimal & 2400 & \\
\hline & Rata-rata kelas & 79,41 & \\
\hline & Ketuntasan belajar & & \\
\hline & & & \\
\hline
\end{tabular}

Gambar 7: Tabel Prosentase Ketuntasan Hasil Belajar Peserta Didik Pada Siklus I

\begin{tabular}{|l|l|l|l|}
\hline $\begin{array}{l}\text { Kreteria Ketuntasan Minimal } \\
(\mathrm{KKM}) 67\end{array}$ & $\begin{array}{l}\text { Frekuensi } \\
\text { (Peserta didik) }\end{array}$ & Prosentase & Keterangan \\
\hline$\geq 67$ & 19 & 79,17 & Tuntas \\
\hline$<67$ & 5 & 20,83 & Tidak Tuntas \\
\hline Nilai terendah & 30 & & \\
\hline Nilai tertinggi & 100 & & \\
\hline
\end{tabular}

Tabel 5 dan 6 menunjukkan bahwa hasil belajar mata pelajaran Fiqih MTs Negeri 5 Klaten Kelas VIII A semester gasal Tahun Pelajaran 2020/2021 pada siklus I telah terjadi peningkatan dengan rata-rata kelas sebesar 80,41 dengan prosentase ketuntasan belajar sebesar $79,17 \%$ dan secara klasikal nilai ketuntasan belajar peserta didik telah tercapai. Bahkan peserta didik yang sebelumnya tidak mengikuti tes,setelah dimotivasi akhirnya semua mengikuti tes.

Selanjutnya pada pelaksanaan siklus II guru telah melakukan perbaikan proses pembelajaran dengan memanfaatkan E-Learning Madrasah sebagai media pembelajaran Mata Pelajaran Fiqih pada Kelas VII A Semester Gasal Tadi MTs Negeri 5 Klaten pada Kelas VII A Semester Gasal Tahun Pelajaran 2020/2021 . Hasil belajar peserta didik pada siklus II sebagai berikut: 
Tabel 7: Tabel Nilai Hasil Belajar Pesereta Didik Pada Siklus II

\begin{tabular}{|l|l|c|l|}
\hline No & Nama Peserta didik & Nilai & Keterangan \\
\hline 1 & Achmad Gerrad Abdul Hafidz & 100 & Tuntas \\
\hline 2 & Muhammad Rizqi Firdaus & 100 & Tuntas \\
\hline 3 & Anggi Adelia & 100 & Tuntas \\
\hline 4 & Muhammad Fathun Ni'am & 100 & Tuntas \\
\hline 5 & Nanda Hermawan & 100 & Tuntas \\
\hline 6 & Kirena Yuki Mustikaningrum & 100 & Tuntas \\
\hline 7 & Bunga Cesaria Agustin & 100 & Tuntas \\
\hline 8 & Cinde Mas K Wijoyo Witjaksono & 100 & Tuntas \\
\hline 9 & Nayshila Rasya fauziah & 100 & Tuntas \\
\hline 10 & Firnanda Kusuma & 100 & Tuntas \\
\hline 11 & Zulfa Agustin & 90 & Tuntas \\
\hline 12 & Bilqis Chairunnisa' Azzura Sutrisno & 90 & Tuntas \\
\hline 13 & Fiqhan Rodzian & 90 & Tuntas \\
\hline 14 & Luthfia Rahmawati & 90 & Tuntas \\
\hline 15 & Ridwan Adi Kusuma & 90 & Tuntas \\
\hline 16 & Erlin Febriyanti & 80 & Tuntas \\
\hline 17 & Malik Fajar Muhammad & 80 & Tuntas \\
\hline 18 & Syifa Ayu Rahmadhanti & 80 & Tuntas \\
\hline 19 & Fathia Aziza Nirmala & 80 & Tuntas \\
\hline 20 & Diva Faulisa Ariana & 80 & Tuntas \\
\hline 21 & Firda Shakiyah Nia Aprilia & 80 & Tuntas \\
\hline 22 & Fitri Wulandari & 80 & Tuntas \\
\hline 23 & Difa Tri Lestari & 70 & Tuntas \\
\hline 24 & Silvia Fatehatu Rahma & 2150 & \\
\hline & Jumlah Skor Nilai & & \\
\hline & Jumlah Skor Maksimal & Tuntas \\
\hline & Rata-Rata Kelas & & \\
\hline & Ketuntasan Hasil Belajar & & \\
\hline & & & \\
\hline
\end{tabular}

Gambar 8: Tabel Prosentase Ketuntasan Hasil Belajar Peserta Didik Pada Siklus II

\begin{tabular}{|l|l|l|l|}
\hline $\begin{array}{l}\text { Kreteria Ketuntasan Minimal } \\
(\mathrm{KKM}) 67\end{array}$ & $\begin{array}{l}\text { Frekuensi } \\
(\text { Peserta didik) }\end{array}$ & Prosentase & Keterangan \\
\hline$\geq 67$ & 24 & 100 & Tuntas \\
\hline$<67$ & 0 & 0 & Tidak tuntas \\
\hline Nilai terendah & 70 & & \\
\hline Nilai tertinggi & 100 & & \\
\hline
\end{tabular}

Tabel 7 dan 8 menunjukkan bahwa hasil belajar peserta didik setelah dilakukan tindakan pemanfaatan media E-Learning Madrasah sebagai media pembelajaran telah terjadi peningkatan sebesar 89,58 dengan prosentasi ketuntasan belajar sebesar $100 \%$. dengan prosentase $100 \%$. Perbandingan hasil belajar Mata pelajaran Fiqih di MTs Negeri 5 Klaten pada Kelas VIII A sebelum tindakan (pra siklus),siklus I dan siklus II dapat penulis sajikan dalam bentuk diagram sebagai berikut : 


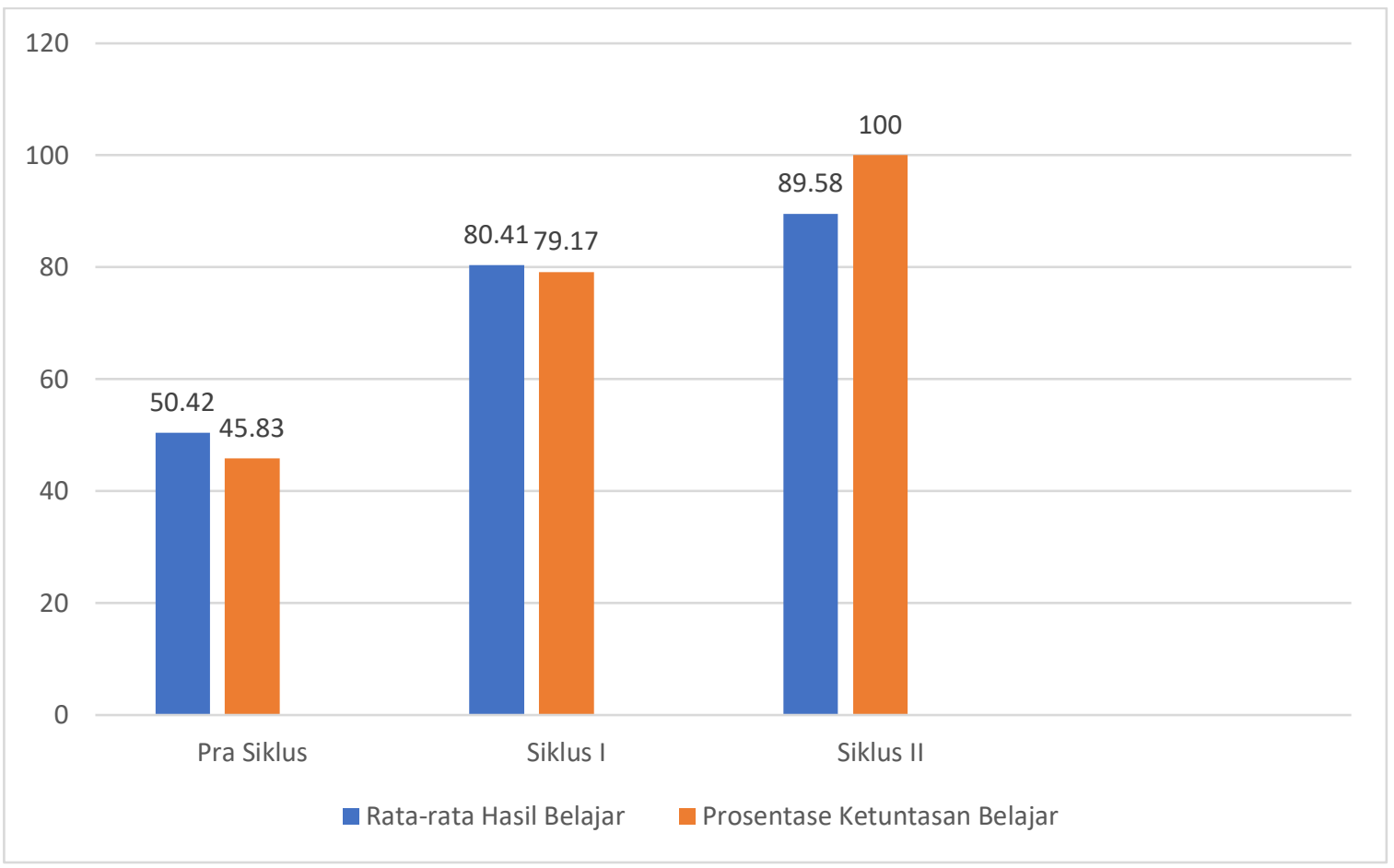

Gambar 2. Perbandingan Hasil Belajar dan keluntasan Belajar Mata Pelajaran Fiqih Kelas VIII A MTs Negeri 5 Klaten

Berdasarkan hasil penelitian yang penulis lakukan pada kelas VIII A MTs Negeri 5 Klaten semester gasal tahun pelajaran 2020/2021 dengan pemanfaatan E-Learning Madrasah sebagai media pembelajaran jarak jauh mata pelajaran Fiqih menunjukkan adanya peningkatan dari sebelum tindakan rata-rata kelas hanya sebesar 50,42 dan prosentase ketuntasan sebesar 45,83 dengan kualifikasi kurang. Kemudian setelah tindakan pada siklus I mencapai rata-rata hasil belajar sebesar 80,41 dengan kualifikasi cukup baik dan ketuntasan belajar telah mencapai $79,17 \%$ berarti masih ada 5 anak dari jumlah 24 peserta didik yang tidak tuntas. Kemudian dilakukan upaya perbaikan di siklus II dan hasilnya rata-rata hasil belajar peserta didik telah mencapai peningkatan yaitu sebesar 89,58 dan prosentase ketuntasan belajar sebesar $100 \%$. Maka jika kita bandingkan rata-rata hasil belajar dan ketuntasan belajar sejak pra siklus,siklus I maupun siklus II terjadi peningkatan yang signifikan.

Hasil penelitian ini sesuai dengan penelitian sebelumnya yang dilakukan sebelumnya oleh Numiek Sulistyo Hanum (2013)bahwa pelaksanaan pembelajaran e-learning di SMK Telkom Sandhy Putra Purwokerto cukup efektif dengan kecenderungan 77,27 \%. Hasil penelitian ini juga sesuai dengan penelitian yang dilakukan oleh Lilis Ardini,Ulfah setia Iswara dan Endang Dwi Retnani (2020) dimana penggunaan e-Learning dinilai oleh mahasiswa cukup efektif sebagai metode pembelajaran. Dengan demikisn e-learning Madrasah sebagai media pembelajaran jarak jauh lebih efektif dapat meningkatkan motivasi dan minat anak dalam belajar.

\section{KESIMPULAN}

Berdasarkan hasil analis dan pembahasan tersebut diatas maka dapat disimpulkan bahwa Pemanfaatan E-learning Madrasah sebagai media pembelajaran mata pelajran Fiqih pada kelas VIII A MTs Negeri 5 klaten semester gasal tahun pelajaran 2020/2021 terbukti dapat meningkatkan rata-rata hasil belajar peserta didik secara signifikan yaitu dari pra siklus 50,42 , kemudian pada siklus I terjadi peningkatan sebesar 80,41 dan pada tahap akhir siklus II meningkat sebesar 89,58. Dengan demikian E-Learning Madrasah sangat efektif sebagai media pembelajaran mata pelajaran Fiqih di MTs Negeri 5 Klaten 


\section{DAFTAR PUSTAKA}

Arikunto,Suharsimi.,dkk (2008).Penelitian Tindakan Kelas. Jakarta:Bumi Aksara.

Arsyad,A.,Media pembelajaran. Jakarta:PT.Raja Grafindo Persada 2010

Djamarah,Syaiful Bahri dan aswan Zain.(2010).Strategi belajar mengajar.Jakarta : Rineka Cipta

Hanum,Numiek.(2013).Keefektifan E-Learning sebagai media pembelajaran(studi evaluasi model pembelajaran E-Learning SMK Telkom Sandhy Putra Purwokerto).Jurnal Pendidikan Vokasi

Jauharul. (2016).Pengembangan Aplikasi Evaluasi Pembelajaran Online Untuk Pendidikan jarak Jauh.ISSN.Vol 26 September :1693-8739.Web 12 Oktober 2020.

Lilis Ardani,Ulfah Setia Iswara,Endang Dwi Retnani E.D.Efektifitas Penggunaan E-Learning sebagai Media Pembelajaran Saat Pandemi Covid 19.JKM (Jurnal konsep Bisnis dan manajemen.ISSN 2407-2648.7 (1) November 2020 